\title{
Richtlijn multisource feedback voor de aios
}

\author{
M.A. Horsman, Th.J. ten Cate
}

\section{Voorwoord}

De opdracht tot het ontwerpen van een In VIVO Richtlijn multisource feedback (MSF) is verleend aan het In VIVO kernteam Onderwijs- en Opleidingsregio (OOR) Utrecht, in samenwerking met OOR Amsterdam/AMC. In de taakverdeling is de Richtlijn ontwikkeld en geschreven door drs. Manon Horsman en prof. dr. Olle ten Cate (beiden UMC Utrecht), en is de toepassing ervan in diverse stadia uitgevoerd met medewerking van specialisten en aios van de kernteams Utrecht en Amsterdam/AMC. Bijzondere dank is verschuldigd aan dr. Joost Frenkel, dr. Anjoke Huisjes, prof. dr. Gerard Visser, dr. Gert van Enk en prof. dr. Maas-Jan Heineman, en aan drs. Lars van de Plank voor de vervaardiging van het programma Multisourcefeedback.nl.

De auteurs hebben gepoogd met deze richtlijn een onderbouwing te geven van de opzet van de procedure en van de gemaakte keuzes met het doel de procedure inzichtelijk te maken. De MSF procedure die wordt geadviseerd in deze Richtlijn, en is onderzocht in de opleidingsregio's Utrecht en Amsterdam, heeft als beoogd doel aios van verschillende specialismen op gezette momenten tijdens de opleiding bruikbare feedback te geven over hun functioneren. Met deze feedback vanuit verschillende perspectieven kan zowel de aios als opleider meer inzicht verkrijgen in wat al goed gaat en op welke punten verbetering nodig is.

Het zal belangrijk zijn de Richtlijn na twee tot vier jaar ervaring met MSF te herzien.

\section{Status van de Richtlijn}

Deze Richtlijn is ontwikkeld in het kader van het In VIVO-project, ${ }^{1)}$ gebaseerd op literatuuronderzoek en beperkt onderzoek in de praktijk. De Richtlijn heeft de status van een advies aan opleiders en opleidingsteams. Multisource feedback (MSF) procedures zijn niet voorgeschreven in het Kaderbesluit Centraal College Medische Specialismen (CCMS) 2009, maar worden wel sterk aangeraden. Omdat met MSF nog maar op beperkte schaal ervaring bestaat in Nederland, is het gewenst op basis van ervaringen en onderzoek de Richtlijn te blijven ontwikkelen.

Een conclusie die getrokken is op basis van het werk dat aan deze Richtlijn is voorafgegaan, is dat MSF op enige schaal van betekenis niet zonder elektronische gegevensverwerking kan. Om deze reden is door de auteurs een programma ontwikkeld waarmee de in deze Richtlijn beschreven methode kan worden uitgevoerd. ${ }^{2)}$ Adviezen over MSF zonder dit of een vergelijkbaar programma zijn naar het oordeel van de auteurs niet zinvol, want dan is MSF te arbeidsintensief, te

1) zie http://www.medischevervolgopleidingen.nl//content/documenten/invivo/1.pdf

2) zie: http://www.multisourcefeedback.nl 
privacygevoelig en te administratief voor een praktische uitvoering. Hoewel de Richtlijn los staat van dit programma, wordt op een aantal plaatsen in de verantwoording eraan gerefereerd en is een beschrijvende passage eraan gewijd.

\section{Inleiding}

De beoordeling van artsen in opleiding tot specialist (aios) is te verdelen in drie benaderingen van hun competentie en te vertalen in drie vragen:

\section{Wat weet de arts?}

Het antwoord op deze vraag is goed te ontlenen aan de resultaten van schriftelijke of computergestuurde toetsing, al of niet in de vorm van een voortgangsmeting.

\section{Wat kan de arts?}

Voor deze vraag leent zich de directe observatie van handelen, in zoveel uiteenlopende situaties als nodig is. Dat kan in de dagelijkse praktijk via Korte Praktijk Beoordelingen (KPB) en in gearrangeerde omstandigheden met simulatietechnieken zoals de Objective Structured Clinical Examination (OSCE) en Objective Structured Assessment of Technical Skills (OSATS). Ook wordt hiertoe de beoordeling van producten zoals een status, protocol of wetenschappelijk verslag gerekend.

\section{Hoe functioneert de arts?}

Deze vraag wordt beantwoord door middel van een evaluatie van het functioneren over een periode in het verleden (week tot enkele maanden). Meerdere beoordelaars (ook wel bronnen genoemd) zijn hiervoor nodig, omdat zij onderling verschillen in hun oordeel en omdat meerdere perspectieven uit het werkveld nodig zijn voor een adequaat beeld van het functioneren. Daarom wordt gesproken van multi- source feedback (MSF) of 360 graden beoordeling. Deze feedback heeft primair een formatief doel: de resultaten van de beoordelingen worden door de aios gebruikt voor reflectie en voor het opstellen van leerdoelen en van een plan van aanpak met als uiteindelijk doel verbetering van het functioneren. Het signaleren van niet goed functionerende artsen kan een secundair meer summatief doel van de feedback vormen.

De MSF procedure is bedoeld om te worden toegepast in combinatie met het voortgangsgesprek dat de opleider heeft met de aios. De MSF rapportage en het voortgangsgesprek zijn complementair: zonder gesprek mist de rapportage de kracht van een afgewogen synthese met afspraken over de toekomst, en zonder goede documentatie mist het voortgangsgesprek diepgang. Beide hebben elkaar nodig.

\section{Geschikte beoordelaars (bronnen)}

Voor het geven van MSF wordt onderscheid gemaakt in drie groepen beoordelaars of bronnen:

- Collegae: supervisor, staflid (dienst), opleider, consulent, coassistent, aios (peers), aios in hogere opleidingsjaren of in aanpalende disciplines waarmee frequent contact bestaat, arts niet in opleiding tot specialist (anios), huisarts/verwijzend arts.

- Andere werkers in de zorg: verpleegkundige, verpleegkundig teamleider/verpleegkundige van management, gespecialiseerd verpleegkundige, verloskundige, paramedicus (fysiotherapeut, diëtist), psycholoog, pedagogisch medewerker, medisch secretaresse, maatschappelijk werker, nurse practitioner, physician assistant.

- Patiënten: volwassenen vanaf 16 jaar of ouders van kinderen jonger dan 16 jaar. 
Tabel 1. Categorieën beoordelaars en de CanMEDS competentiegebieden die zij kunnen beoordelen.

\begin{tabular}{lccc}
\hline Competenties CanMEDS & Collegae & Andere werkers in de zorg & Patiënten \\
\hline Medisch handelen & ++ & \pm & - \\
Communicatie & ++ & ++ & ++ \\
Professionaliteit & ++ & ++ & ++ \\
Organisatie & ++ & ++ & \pm \\
Samenwerking & ++ & ++ & - \\
Kennis en wetenschap & ++ & + & - \\
Maatschappelijk handelen & \pm & \pm & - \\
\hline
\end{tabular}

++ zeer geschikte bron; + geschikte bron; \pm minder geschikte bron; - ongeschikte bron.

\section{Te beoordelen competenties}

Tabel 1 geeft de categorieën beoordelaars weer die geschikt zijn voor het beoordelen van de diverse competentiegebieden, gerelateerd aan het CanMEDS model. Het CanMEDS competentiegebied Maatschappelijk handelen is minder makkelijk of geschikt voor MSF beoordelingen en is daarom buiten beschouwing gelaten. ${ }^{3}$ )

\section{Selectie en benadering van beoorde- laars}

Geadviseerd wordt de aios zelf verantwoordelijk te laten zijn voor het selecteren van beoordelaars en voor het toesturen van de vragenlijsten. De literatuur geeft aan dat hier weinig bezwaar tegen is. Dat kan bijvoorbeeld via het programma Multisourcefeedback.nl. Per groep beoordelaars wordt het volgende minimum aantal beoordelaars geadviseerd:

- Collegae: minimaal zes beoordelaars, waaronder twee stafleden van het opleidingsteam (in ieder geval de huidige supervisor), twee peers (aios in zelfde fase van de opleiding). Overige medische collegae zijn meestal coassistenten en collegae met wie tijdens een dienst (weekend/week) is samengewerkt.

- Andere werkers in de zorg: minimaal zes beoordelaars, waaronder vier verpleegkundigen. Bij voorkeur geen medische secretaresses of andere beoordelaars die weinig aanwezig zijn bij patiëntenzorg.

- Patiënten: minimaal tien beoordelaars. Bij voorkeur een gemengde patiëntenpopulatie van poliklinische en klinische patiënten en minimaal twee patiënten waarmee meerdere contacten zijn geweest.

In het programma Multisourcefeedback.nl worden de vragenlijsten van patiënten anoniem verwerkt. Beoordelaars in de medische en niet medische groep wordt wel gevraagd naar hun naam en beroepsgroep, zodat de opleider zo nodig mondeling toelichting kan vragen aan de betreffende beoordelaar. De aios krijgt in

3) De NVMO Reviewcommissie Richtlijnen is van oordeel dat dit competentiegebied wellicht wel kan worden meegenomen. Bij een herziening van deze Richtlijn kan hiermee rekening gehouden worden. 
het MSF programma alleen de gemiddelde scores per groep beoordelaars te zien en geen individuele scores van collegae. De geschreven opmerkingen worden onherleidbaar gemaakt. Maar anonimiteit heeft ook nadelen. Het past niet binnen een opleidingsklimaat waarin iedereen leert verantwoording af te leggen over oordelen en beslissingen. Anderzijds bestaat de kans dat bij niet anonieme enquêtering men zich minder vrij kan voelen in het geven van een oordeel. Op dit punt zal de Richtlijn in de toekomst nader geëvalueerd moeten worden.

\section{Frequentie en tijdstip beoordeling}

Geadviseerd wordt het tijdstip van een MSF procedure aan te passen aan het opleidingsschema. Geadviseerd wordt de MSF procedure ieder opleidingsjaar éénmaal uit te voeren, maar bij voorkeur niet bij stages die korter zijn dan drie maanden. Er is beperkte maar goede ervaring opgedaan met een collectieve jaarlijkse MSF procedure, met het beschreven MSF programma voor alle aios van een opleiding, en met de planning van alle voortgangsgesprekken binnen één maand. Op indicatie kan de MSF procedure eventueel na een half jaar worden herhaald.

\section{De vragenlijsten}

Voor iedere groep beoordelaars is een vragenlijst ontworpen, gebaseerd op literatuuronderzoek en op overleg met experts. Naast gesloten vragen over de verschillende competenties wordt bij alle vragenlijsten gevraagd naar tips en aanwijzingen die het functioneren van de arts kunnen verbeteren. Tevens wordt gevraagd naar de periode waarover zij de aios beoordelen; aan patiënten wordt gevraagd het aantal contacten dat zij met de aios hebben gehad te vermelden. Voor pediatrische patiënten is de vragenlijst enigszins aangepast en wanneer kinderen te jong zijn om de vragen te begrijpen, wordt gevraagd naar de mening van de ouders. Mutatis mutandis kunnen de patiëntenvragenlijsten worden ingevuld door begeleiders van patiënten die om andere redenen niet in staat zijn de vragenlijst in te vullen. De vragenlijst is tevens beschikbaar in het Engels. Vragenlijsten voor niet-westerse allochtone patiënten zijn in ontwikkeling.

\section{Logistiek en verwerking van gegevens}

De hoeveelheid gegevens die verwerkt moet worden voor een MSF procedure is groot. De auteurs beperken zich daarom tot de beschrijving van het ontwikkelde elektronische programma. Met het webbased programma multisourcefeedback.nl kan de opleider vanaf iedere internetaansluiting een feedbackprocedure opstarten door e-mailadressen van de betreffende aios in te voeren en voor een voortgangsgesprek een uiterste datum vast te leggen, waarop de procedure moet zijn afgerond. Bij voorkeur dient een MSF-ronde drie tot zes maanden vóór deze datum te worden gestart, zodat er voldoende tijd is voor de beoordelingen. De aios krijgt vervolgens per e-mail instructie om beoordelaars uit te nodigen een vragenlijst in te vullen over het functioneren door hun e-mailadres in te voeren. De aios is verantwoordelijk voor de medewerking van voldoende en zo relevant mogelijke beoordelaars (totaal minimaal 22 vragenlijsten). In het programma kan de voortgang van de procedure bekeken worden door zowel aios als opleider en kan een herinnering verstuurd worden aan de beoordelaars. Eén week vóór de datum van het voortgangsgesprek wordt de feedbackronde automatisch afgesloten en wordt een samenvattend rapport opgemaakt in het programma. Hierin worden de gemiddelde scores per vraag, per competentiegebied en per groep beoordelaars weergegeven, evenals 
een overzicht van de opmerkingen die door de beoordelaars zijn gemaakt. Deze resultaten zijn bedoeld om door de opleider met de aios te bespreken in het daaropvolgende voortgangsgesprek. Samenvattingen van voltooide feedbackprocedures blijven gedurende de opleiding bewaard in het programma.

\section{Implementatie van multisource feedback}

In de verantwoording zijn de voorwaarden beschreven voor een goede invoering van het proces en worden mogelijke weerstanden besproken. MSF is nog betrekkelijk onbekend in de vervolgopleidingen en voor een succesvolle implementatie is het essentieel dat stafleden en medewerkers bekend zijn met het principe, zodat het uitzetten van de formulieren niet als een verrassing komt. De weergegeven tekst in Box 1 kan hiervoor gehanteerd worden om te versturen en meer informatie is te downloaden van www.multisourcefeedback.nl.

Daarnaast is training van opleiders in het geven en bespreken van feedback met behulp van MSF nuttig. Dit kan geïntegreerd worden in cursussen over het opleiden en opleidingsvernieuwingen. Is men bekend met de MSF procedure, dan is de inspanning betrekkelijk gering en zeer gespreid over alle betrokkenen. De administratieve inspanning is minimaal.

Box 1. Concepttekst voor een folder of rondschrijven.

Wat is multisource feedback?

Artsen in opleiding tot specialist (aios) worden tijdens hun opleiding beoordeeld op wat zij weten, wat zij kunnen en hoe zij functioneren. Het functioneren van een aios kan het beste beoordeeld worden door mensen met wie hij/zij samenwerkt: collega-artsen, andere collegae in de zorg en patiënten. Dit proces van beoordeling door verschillende beoordelaars wordt multisource feedback (MSF) genoemd. Eénmaal per jaar worden artsen, andere werkers in de zorg en patiënten door de aios gevraagd een vragenlijst in te vullen. De vragenlijsten worden anoniem verwerkt: de aios krijgt de antwoorden niet te zien, alleen de gemiddelde scores van de bevraagde collegae en patiënten. Bij een negatieve score op een bepaald gebied zal de opleider voor verduidelijking eventueel contact opnemen met degenen die een negatieve score hebben gegeven. De aios krijgt door MSF een beeld van zijn/haar sterke en minder sterke kanten en kan dan zo nodig werken aan verbetering.

Voor meer informatie over het doel en werkwijze van MSF: zie www.multisourcefeedback.nl en de Richtlijn Multisource Feedback (Tijdschrift voor Medisch Onderwijs 2010;29 (2); suppl. 1). 